\title{
How does fiscal austerity impact on poverty and inequality? The Spanish case
}

\author{
P. Campoy-Muñoz ${ }^{1}$ (D) M. A. Cardenete ${ }^{2,3}$ (D) F. J. De Miguel-Vélez ${ }^{4}$. \\ J. Pérez-Mayo ${ }^{4}(\mathbb{D}$
}

Received: 4 February 2021 / Accepted: 11 December 2021 / Published online: 7 January 2022

(c) The Author(s) 2022

\begin{abstract}
The aim of this paper is contributing to fill the gap between the macroeconomic effects of policy reforms and the microeconomic and social ones, considering simultaneously both kind of impacts. Regarding fiscal adjustments, concern about the sustainability of public deficit and debt resulting from the Great Recession led governments to adopt austerity measures in most European countries. Our analysis considers the redistributive effects of such adjustments for the Spanish economy by simulating a hypothetical reduction of public deficit and distinguishing between spending cuts and tax hikes. In terms of analytical approach, a Computable General Equilibrium (CGE) model and a microsimulation model are integrated to include the general equilibrium effects of these measures as well as the effects on income distribution. The results contribute to the growing but limited literature on the distributional effects of fiscal consolidations by showing that policymakers have to choose between more inequality or more poverty.
\end{abstract}

Keywords Computable general equilibrium model $\cdot$ Inequality $\cdot$ Microsimulation · Poverty $\cdot$ Spain

JEL Classification C63 $\cdot$ C68 $\cdot$ D63

\section{Introduction}

The analysis of public policies and their impact in the citizens' actual living conditions shows a relevant gap: partial evaluations are usually performed. Sometimes, macroeconomic aggregates -GDP growth, inflation, unemployment rate...- are used

\footnotetext{
P. Campoy-Muñoz

mpcampoy@uloyola.es

$\triangle$ J. Pérez-Mayo jperez@unex.es
}

Extended author information available on the last page of the article 
to assess if the policies are adequate, neglecting the effects on poverty and inequality. Even, a well-designed macroeconomic policy can raise the level of political or social discontent among the population due to an increasing level of impoverishment. On the other side, some policies aimed at alleviating poverty or reducing inequality can entail harmful effects on the economic dynamics. The aim of this paper is contributing to close this gap by focusing the analysis on the Great Recession, a good example of this dilemma.

This deep crisis, started in the late 2000s, led to an unprecedented increase in public deficit and debt, especially in some European countries. Amongst policymakers, it is widely agreed that fiscal imbalances, illustrated by excessive and longstanding public deficit-to-GDP ratios, are harmful for growth and macroeconomic stability (Coenen et al., 2008). Combinations of spending cuts and tax hikes were undertaken to reduce ratios of public deficit or debt over GDP and, in turn, to sustain the path of debt growth.

The make-up of such consolidation packages matters for the prospect for economic recovery, but also for distributional effects in a context of widening income inequality (IMF, 2015), specifically in the aftermath of the economic and financial crisis (Salotti \& Trecroci, 2018). However, there is a lack of common understanding of how austerity measures have interacted with the decisions of national economic agents and how both have led to changes in income levels and distribution. This is especially relevant in the short term since effects of fiscal consolidation are being broadly considered harsher than previously thought (Paulus et al., 2017).

In this context, a growing body of empirical evidence on the macroeconomic effects of austerity has emerged. This literature is mostly focused on interactions between the policy mix and the economic output ${ }^{1}$ while only a few studies have looked at determining the distributional impacts of such fiscal adjustments. The latter analysed several fiscal consolidation episodes, highlighting that such measures are typically associated with an increase in income inequality mainly as a result of spending cuts rather than tax hikes adjustments (Agnello \& Sousa, 2014; Ball et al., 2013; Coenen et al., 2008; Woo et al., 2017).

On the other hand, microsimulation models have also been used to estimate the effects of fiscal reforms on households' income distribution and living conditions. ${ }^{2}$ These models are based on microdata related to income, expenditures, or tax revenues. Therefore, the impact of economic shocks on income distribution can be evaluated ex ante. EUROMOD model is one of the most important contributions in this literature. Some publications from this project as Avram et al. (2013), Matsaganis and Laventi (2014), Paulus et al. (2017) or Ayala and Paniagua (2019) try to estimate these impacts. $^{3}$

Although these models can estimate very accurately changes on income distribution, tax collection or households' expenditure caused by reforming or applying

\footnotetext{
1 See Ball et al. (2013) and Agnello and Sousa (2014) for a selection of the main literature on this topic.

2 See, for example, the seminal reference by Bourguignon and Spadaro (2006).

3 Other microsimulation proposals for Spain can be found in ESPASIM (Levy et al., 2001), SINDIEF (Sanz et al., 2003), SIRPIEF (Sanz et al., 2004), GLADHISPANIA (Oliver and Spadaro, 2004), FUNCASim (Sanz et al., 2009), Ayala and Paniagua (2016) or Granell and Fuenmayor (2019).
} 
new taxes, a partial equilibrium approach is usually followed (Bargain \& Callan, 2010; Callan et al., 2011). Therefore, despite of measuring the outcomes in terms of income distribution, not all the effects of these policies are included in the analysis. ${ }^{4}$ All fiscal reforms, though related to a specific economic sector, end up to impact on the whole economy through different channels, so all the second-order effects are ignored in the microsimulation models.

The distributional issues of fiscal policies are also assessed under the general equilibrium framework, which has been gradually enriched to overcome the limitation of the representative agent assumption. Recently, New Keynesian Dynamic Stochastic General Equilibrium (NK-DSGE) models have been employed to study the impact of fiscal policies on inequality by incorporating household heterogeneity by means of two or more types of households, according to the behaviour showed in household-level income-expenditure databases (Kaplan \& Violante, 2018; Mc Manus et al., 2021). The main drawback of such models is the use of nontrivial computational techniques for solving them, given the need of tracking the distribution of wealth and the obstacles due to binding borrowing constraints. As a result, their usefulness as an input for policy making may be limited due the difficulties in understanding the mechanism underlying their findings (Debortoli \& Galí, 2017).

In the same way, Computable General Equilibrium (CGE) models, which are widely used in policy analysis, have grouped households according to several categories based on socio, economic or geographic criteria. This approach along with the use of the abovementioned household-level databases can be used to perform poverty analysis and capture adequately distributive impacts, but heterogeneity is limited to inter-group changes (Cockburn et al., 2014). In a further step to capture intra-group distributional effects, all individual households from a household survey can be incorporated into the CGE model, which is known as fully integrated approach. The drawbacks of this latter approach have limited their use and have led to integrate microsimulations into CGE models (Cockburn et al., 2014).

In this paper, a static and integrated Computable General Equilibrium - microsimulation modelling approach is used with the aim of assessing the effects of fiscal consolidation on aggregate output, unemployment, inequality, and poverty, differentiating the effects caused by spending cut or tax hikes. ${ }^{5}$ This top-down combination allows incorporating both the general equilibrium effects and the full household heterogeneity. This issue is very relevant to avoid the aggregation bias (Paulus et al., 2017). Since households are different in composition, size, and income sources, such consolidation measures may lead to opposed household-specific inequality and poverty effects.

Figure 1 shows in detail the development of the approach applied in this article where it can be clearly seen how the two empirical models-CGE and microsimulation-are linked. This process starts with the calibration and computation of a static

\footnotetext{
${ }^{4}$ The new methodology of EUROSTAT to obtain flash estimates of income and poverty indicators considers the effect of some macroeconomic covariates to simulate the effects, but it omits the second-order effects in the economy. (https://ec.europa.eu/eurostat/cros/content/flash-estimates-income-and-povertyindicators_en).

${ }^{5}$ Some examples of CGE-microsimulation models used to analyse fiscal reforms can be found in Ahmed et al. (2010), Llambi et al. (2016), Feltenstein et al. (2017) or Schubert (2018).
} 


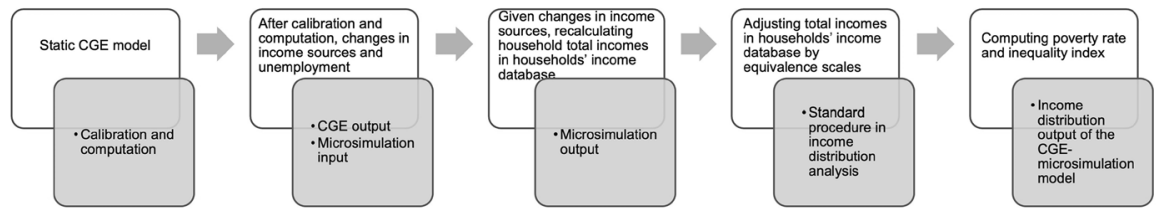

Fig. 1 Top-down CGE-microsimulation approach. Source: Authors' elaboration

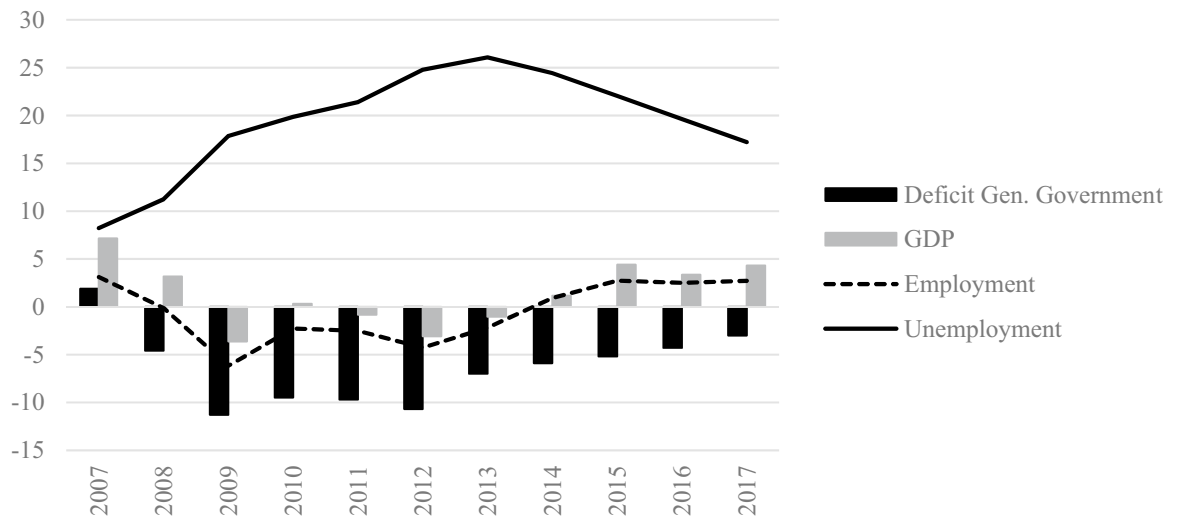

Fig. 2 Main aggregates of Spanish economy. Source: Bank of Spain (2021) and National Statistical institute (2021a, b). Note: Deficit General Government (\%GDP); GDP and employment (annual rate of change); unemployment (rate)

CGE model that outputs the macroeconomic effects of the proposed simulations. Since a top-down approach is used in the CGE-microsimulation link, the changes in labour and capital incomes, obtained in the computation of the CGE model (top), are used as input in the microsimulation of the counterfactual income distribution (down). Specifically, new labour income, capital income and unemployment benefits for each household are recalculated according to the changes computed in the CGE model. Once the "new" counterfactual income distribution is obtained, the usual techniques are applied to obtain the poverty and inequality measures.

Specifically, using Spanish economy in 2014 as the benchmark, two simulations are performed to estimate the effects of a reduction of the public deficit ratio up to 3\%: (1) an increase of the value added tax and (2) a decrease of the public spending. Spain becomes relevant as a particular case of study due to several features. This country deeply suffered the Great Recession, failing to meet the commitments on the deficit set out in the European Union Pact of Stability and Growth since 2008 (Fig. 2). As a result, the Spanish government drew up successive stability programmes adopting a series of fiscal consolidation measures to meet the deficit target (Spanish Government, 2021). The first of these was for the period 2009-2011, in which the deficit target was expected to be reached in 2011 (Spanish Government, 2010). However, the evolution of the Spanish economy made it impossible to 
embark on a path of sustained deficit reduction until 2014, that would culminate in the achievement of the stability target in 2017. In fact, in 2014 employment and output grew in annual terms for the first time since the onset of the crisis (Spanish Government, 2014). The measures to carry out this fiscal consolidation were established by the Spanish government including expenditure and revenue measures, unlike other countries in the European periphery with marked public deficits and mostly expenditure-based fiscal consolidation as imposed by IMF or EU (Bajo-Rubio \& Gómez-Plana, 2015). Thus, in addition to a reduction in public expenditure, on the revenue side, the economic recovery led to an improvement in the components of the revenue structure, including private consumption, which boosted VAT revenues among others.

However, none of these programmes analyse the impact of such fiscal consolidation measures on poverty and inequality, especially in this context of economic recovery, which is particularly relevant as the Spanish data report a slight increasing trend due to the decreasing poverty thresholds. ${ }^{6}$ At the same time, income inequality rose from the beginning of the economic crisis (Amuedo-Dorantes \& Borra, 2018).

Therefore, the process undertaken attempts to simulate the counterfactual situation of not really adopted policies, taking the real situation as a starting point. In other words, it attempts to reflect what would have happened if, in addition to the economic and financial crisis, the policies simulated in the article had been adopted.

The remainder of the paper is organized as follows. Section 2 briefly presents the CGE model, while Sect. 3 is devoted to the microsimulation model. Section 4 describes the databases employed in the study and Sect. 5 depicts the main results. Finally, Sect. 6 offers the conclusions.

\section{The CGE model}

In general terms, a CGE model encompasses all the economic interactions within a given economy, depicting the circular flow of income. Specifically, these models provide a complete representation of the different economic agents, assuming an optimization behaviour for them. The model equilibrium is determined by a price levels vector and an activity levels vector that clear markets and allow agents to reach their optimizations plans. Therefore, the model can be mathematically represented as a set of equations containing such equilibrium conditions.

In this work, a static intersectoral CGE model is employed.The model follows the concept of Walrasian competitive equilibrium enlarged to the public and foreign sector, that is, supply and demand should be equal in all non-labour markets. ${ }^{7}$ In particular, the model includes one representative firm in each sector, a single

\footnotetext{
6 The official poverty line in the European Union is relative to the median income. If anchored poverty lines fixed at the same year are used, the increase of poverty rates in Spain is outstanding.

7 In the labour market, there might be a situation of excess of supply or unemployment.
} 
representative consumer, one public sector and one foreign or rest of the world sector. $^{8}$

Starting with the structure of production block, producers combine intermediate inputs (domestic and non-domestic) and primary factors to obtain homogeneous product at least cost subject to technological constrains. Such constrains are described through a nested constant-returns-to-scale technology, so that there will be no excess profits. At the first nested level, total production for each sector is obtained by combining domestic output and equivalent imports, according to a Cobb-Douglass technology function (Armington, 1969). At the second level, the domestic production is a Leontief combination of intermediate inputs and value added. Finally, at the third level, the value added is a Cobb-Douglas aggregate of the primary factors (labour and capital).

Regarding consumers, the CGE model includes a representative household that maximizes the utility derived from consumption and savings by means of a Cobb-Douglas function subject to its disposable income. Households gain income basically as result of the sale of their endowments of labour and capital, but they also receive unemployment benefits, net transfers from the government and transfers from the rest of the world. Disposable income equals households' gross income minus personal income tax and social contributions paid by employees.

Regarding the government, it collects taxes on production, value added tax, tariffs, personal income tax and payments to the Social Security System made by employers and employees. These public revenues are used to pay transfers to the private sector, unemployment benefits and public consumption of good and services. The difference between its revenues and payments represents the public surplus, which is endogenously determined. On the other hand, the government's activity level remains fixed at the base year, although government expenditure may vary due to changes in prices.

Finally, the foreign sector is a simplified agent that includes two trading partners: the European Union and all other countries. Imports, exports, and transfers are exogenously fixed at the base year-level but the current account balance and the aggregate price index for the traded commodities are endogenously determined.

Two additional comments about the model should be pointed out. First, the investment activity is modelled following a fixed-coefficients technology, whose inputs are the sales of the productive sectors to the investment sector and whose output level is driven by the total savings in the economy. Therefore, the closure rule guarantees the macroeconomic equality between the total investment of the economy and savings at the aggregated level. Second, the aggregate labour supply follows the real-wage unemployment equation (Kehoe et al., 1995) that captures the feedback effects between the real wage and the unemployment rate. This feedback represents the frictions in the labour market that cause unemployment (Oswald, 1982).

\footnotetext{
8 See Cardenete and Sancho (2003). A more detailed description of the model containing the main equations is included in the Appendix A.
} 


\section{Microsimulation model}

As it is stated in the introduction, this paper proposes the combination of a CGE model with a microsimulation model to simulate the effects on the households' living conditions, especially on the income distribution. Thus, the outcomes of the computation of the CGE model -the macroeconomic scenarios- are linked to the actual chances of households to face this economic situation.

Before reporting the linking procedure of CGE and microsimulation models, some comments about income should be raised. The income definition considered in this paper is the adjusted or equivalized disposable household income. This variable comes from the total disposable household income, which comprises all the incomes earned by the household members from labour, capital (self-employment, and financial and real estate yields), public transfers or benefits, unemployment benefits and inter-households or private transfers. After adding all those income sources, taxes must be subtracted to obtain net income.

$$
H \text { Income }_{0}=\text { WAGES }_{0}+\text { CAPITAL }_{0}+\text { BENEFITS }_{0}+\text { UNEMPLOYMENT }_{0}+\text { OTHER }_{0}-\text { TAXES }_{0}
$$

Later, differences in needs are considered because different households -in size and composition- with the same net income will have different living conditions. Therefore, the total household income is adjusted by using an equivalence scale, which reports the influence of household size and composition. Among the wide range of options in the literature, the modified OECD equivalence scale ${ }^{9}$ is chosen. Once the household equivalent size is computed, the adjusted household income is determined by dividing the total disposable income by this equivalent size. Finally, the adjusted household income is allocated to each household member before performing inequality and poverty analyses.

Once every individual in the microdata has his/her own equivalent household income, the impact of macroeconomic changes on household incomes can be measured. The procedure is reported in Eq. 2 where the former expression is re-written by including some coefficients of change, built after computing the CGE model.

$$
H \text { Income }_{1}=\text { WAGES }_{1}+\text { CAPITAL }_{1}+\text { BENEFITS }_{1}+\text { UNEMPLOYMENT }_{1}+\text { OTHER }_{1}-\text { TAXES }_{1}
$$

where each variable at time 1 (after computation) is expressed as $X_{i 1}=\gamma_{i} X_{i 0}$, being $i$ the coefficients that reflect the changes in income for each variable. These coefficients are calculated so that the increases or decreases of the total income by source in the microdata database are the variations obtained in the macroeconomic model for those income sources.

Since two values of income, actual equivalent income and simulated equivalent income, are computed, the effects of macroeconomic shocks on the households' earnings could be measured for the whole income distribution and not only in terms

\footnotetext{
${ }^{9}$ This scale gives a weight of 1 to the first adult in the household, 0.5 to the remaining adults and 0.3 to the household members younger than 14 .
} 
of mean incomes. Moreover, the most usual indicators of inequality and poverty can be also applied to estimate and measure the impact on living conditions and well-being.

Among the wide range of indicators proposed in the literature to measure inequality, Gini index and Theil or Generalized Entropy Index will be used. Gini and Theil index have the advantage of summarizing all the information contained in the distribution in a single scalar because they are functions that assign a real number to each income distribution. However, since both follow different aggregation procedures, they report different figures.

The former is the most usually found in the official reports as well as the academic papers. It is defined by the following expression:

$$
G=\frac{1}{\mu} \operatorname{Cov}(x, F(x))
$$

Meanwhile, the Theil index is based on the concept of entropy and, therefore, belongs to the general class of entropy measures (Cowell, 1995). Depending on $c$ parameter, ${ }^{10}$ it can be expressed as:

$$
\begin{gathered}
T_{c}=\frac{1}{n} \frac{1}{c(c-1)} \sum_{i=1}^{n}\left[\left(\frac{y_{i}}{\mu}\right)^{c}-1\right], c \neq 0,1 \\
T_{0}=\frac{1}{n} \sum_{i=1}^{n} \ln \left(\frac{\mu}{y_{i}}\right), c=0
\end{gathered}
$$

The second equation will be used in this paper because of its simplicity. Besides, this index shows a very relevant advantage: it is the only one that satisfies the whole range of desirable properties for an inequality index. No index, excepting Theil, is additively decomposable so that, the general level of inequality measured with a Theil index can be expressed as the sum of partial index weighted by the share of each group in the population.

Finally, the effects on poverty are also analysed in this paper as an outcome of the microsimulation model. Since a relative approach is assumed, the poverty line is fixed at the $60 \%$ of the median equivalent income. ${ }^{11}$ Once the threshold is fixed, a poverty indicator must be selected. Due to their properties, the Foster-Greer-Thorbecke (Foster et al., 1984) -henceforth, FGT- family of poverty measures is chosen to perform the poverty analysis:

$$
\operatorname{FGT}(\alpha)=\frac{1}{n} \sum_{i=1}^{q}\left(\frac{z-y_{i}}{z}\right)^{\alpha}
$$

where $n$ is the population, $q$ the poor population, $y_{i} i$-th individual's income and $z$ the poverty line. This expression includes different definitions of poverty depending

\footnotetext{
10 This $c$ parameter expresses the degree of aversion to inequality.

11 It is the official poverty threshold established by EUROSTAT.
} 
on the $\alpha$ parameter. It expresses the individual' sensitivity to poverty gap regarding to poverty threshold (i.e., distance from the poverty line). The greater the value of this parameter, people with a greater poverty gap will be the more important in the analysis. Therefore, it can be viewed as the degree of aversion to poverty in the population.

In particular, if $\alpha=0$ the FGT index is merely the share of poor people in the population, the so-called "headcount index" or the widely known "poverty rate". It measures the poverty incidence so that there is no information about how much poor are the poor people. This issue, poverty depth, can be observed by the FGT index when $\alpha$ is equal to $1 .^{12}$

\section{Databases}

The database employed to calibrate the CGE model and determine their parameter values ${ }^{13}$ is a Social Accounting Matrix (SAM) for Spain with 2014 data (SAMSPA-14). ${ }^{14}$ Overall, a SAM is a square matrix that shows a disaggregated representation of the circular flow of income, recording information about all the economic transactions within a given economy and period of time. Specifically, the SAMSPA-14 consists of 31 accounts, including 19 productive sectors, 2 inputs (labour and capital), a representative consumer, an aggregate capital account or saving/ investment account, a government account, the taxes accounts according to the disaggregation required by the model, and a foreign sector account.

To calibrate the CGE model, the SAMSPA-14 is reproduced by model as a benchmark equilibrium in which all the prices and the activity levels are unitary at initial time. From this initial condition we introduce an exogenous shock (the reduction of the public deficit), obtaining the changes by comparing the benchmark and the simulated equilibriums.

Regarding the microsimulation model, it is based on the $2015^{15}$ Spanish subset of the EU-SILC (European Union Survey on Income and Living Conditions) microdata. This survey, coordinated by EUROSTAT, aims at allowing the comparability of results across the European Union. Besides, it is specially designed to analyse income and living conditions, so that it is the best database to develop an analysis about microsimulation, inequality, and poverty. Each wave contains four files: D (general information about households), H (specific information about households), $\mathrm{R}$ (general information about persons) and $\mathrm{P}$ (specific information about adult people). Since the individual is used as the unit of analysis and not all the income

\footnotetext{
${ }^{12}$ The inequality among poor people -also named poverty severity- is reported with $\alpha$ equal to 2 . However, the scope of this paper is limited to poverty incidence and depth.

${ }^{13}$ All the parameters can be obtained by calibration, except the unemployment rate for the benchmark equilibrium, which has been set at 24.4 (National Statistical Institute, 2017), and the elasticity of the real wage to unemployment, which has been fixed at 1.2 (García-Mainar and Montuenga-Gómez, 2003). Tax rates are obtained from tax revenues included in the SAM; thus they are effective rather than nominal rates.

${ }^{14}$ See Campoy-Muñoz and Cardenete (2017). The SAM accounts are listed in Appendix B.

15 The income values in EU-SILC microdata are referred to the year before. Therefore, the 2014 wave must be used to keep the temporal homogeneity with the CGE model.
} 
Table 1 Change in macroeconomic variables

\begin{tabular}{|c|c|c|c|c|c|}
\hline & \multirow{2}{*}{$\begin{array}{l}\text { Benchmark } \\
\text { Level }\end{array}$} & \multicolumn{2}{|c|}{ Scenario 1 (VAT) } & \multicolumn{2}{|c|}{$\begin{array}{l}\text { Scenario } 2 \text { (Gov. Spend- } \\
\text { ing) }\end{array}$} \\
\hline & & Level & $\begin{array}{l}\% \text { Change } \\
\text { from bench- } \\
\text { mark }\end{array}$ & Level & $\begin{array}{l}\% \text { Change } \\
\text { from bench- } \\
\text { mark }\end{array}$ \\
\hline Public surplus ratio (\% GDP) & -5.8 & -3.0 & - & -3.0 & - \\
\hline Real GDP $(\mathrm{M} €)$ & $1,036,940$ & $1,015,960$ & $-2.02 \%$ & $1,029,669$ & $-0.70 \%$ \\
\hline Consumer price index & 1 & 1.04 & $3.80 \%$ & 1.01 & $1.10 \%$ \\
\hline Real wage index & 1 & 0.96 & $-3.80 \%$ & 0.99 & $-1.10 \%$ \\
\hline Unemployment rate $(\%)$ & 24.4 & 27.2 & $11.48 \%$ & 25.2 & $3.28 \%$ \\
\hline Labour income $(\mathrm{M} €)$ & 430,839 & 415,132 & $-3.65 \%$ & 426,155 & $-1.09 \%$ \\
\hline Capital income $(\mathrm{M} €)$ & 466,471 & 444,112 & $-4.79 \%$ & 476,522 & $2.15 \%$ \\
\hline Public transfers $(\mathrm{M} €)$ & 206,404 & 214,213 & $3.78 \%$ & 208,672 & $1.10 \%$ \\
\hline Unemployment benefits (M€) & 18,415 & 20,496 & $11.30 \%$ & 19,036 & $3.37 \%$ \\
\hline Public revenues $(\mathrm{M} €)$ & 408,905 & 456,008 & $11.52 \%$ & 406,901 & $-0.49 \%$ \\
\hline
\end{tabular}

M€: EUR millions

Source: Authors' calculation by GAMS

sources appear in all files, it is required to combine the files $\mathrm{H}$ and $\mathrm{P}$ as well as $\mathrm{R}$ to estimate the household income.

After an analysis of prior validation to eliminate extreme values or outliers, the sample employed in the study comprises 31,403 observations. In addition to income, background information such as labour market status, age, sex, household size and type or region are used to perform the proposed analysis.

\section{Simulations and results}

As a first step, the CGE model outlined in the above section is used to simulate the reduction of public deficit until the $3 \%$ of GDP, as established in the Stability and Growth Pact. Simulations have been performed under two scenarios, recalling measures adopted by the Spanish government, as well as other European countries, as an important part of its consolidation package (Paulus et al., 2017). First, the target of deficit could be reached by increasing $2.7 \mathrm{pp}$ the effective value-added tax (VAT). This tax hike does not influence households' disposable income, but it directly impacts on their consumption potential leading a path of changes that may results in changes in income. Second, it is assumed a reduction in government consumption of $14.5 \%$, that is, a decrease in the demand of goods and services by the public sector.

Table 1 reports the results from the two above simulations on the main macroeconomic variables, both as level of the corresponding variable and as percentage change from its benchmark value. As it is shown, both measures have contractionary effects since GDP falls in both scenarios, but such effects are larger for VAT hike than for government spending cut. In both scenarios unemployment 
Table 2 Inequality and poverty after microeconomic simulation

\begin{tabular}{llllll}
\hline & Benchmark & Scenario 1 & \multicolumn{3}{l}{ Scenario 2 } \\
\hline Per capita income mean & $30,220.04$ & $28,576.44$ & $-5.44 \%$ & $29,785.78$ & $-1,44 \%$ \\
Equivalent income mean & $15,762.35$ & $14,946.42$ & $-5.18 \%$ & $15,550.09$ & $-1,35 \%$ \\
Gini index & 0.3363 & 0.3333 & $-0.89 \%$ & 0.3421 & $1,72 \%$ \\
Theil (0) index & 0.2167 & 0.2151 & $-0.74 \%$ & 0.2274 & $4,94 \%$ \\
FGT (0) & 0.2154 & 0.2235 & $3.76 \%$ & 0.2262 & $5,01 \%$ \\
FGT (1) & 0.0781 & 0.0821 & $5.12 \%$ & 0.0842 & $7,81 \%$ \\
\hline
\end{tabular}

Source: Authors' calculation by Stata

increases with a remarkably higher rise under the tax increase compared to the spending cut measure. Regarding prices, the results show an increase in consumer price index and a drop in real wage for both scenarios, especially for VAT based measure.

With respect to the households' sources of income, labour income decreases because of the fall in both employment and real wages, corresponding again the worse result to the tax-based measure. On the other hand, capital income decreases in the VAT hike scenario but improves when spending cut is done. Moreover, the increase in public transfers is mostly paired with the increase in the consumer prices under both scenarios, whereas the rise in unemployment benefits, following the path of the unemployment, is higher in the first than in the second one. Finally, total government revenue exhibits a large rise to achieve the deficit target while it slightly falls when spending cut is performed.

To sum up, all these findings point out that both scenarios show unfavourable results for households, that is, higher unemployment and labour income fall, but the VAT hike scenario results are shockingly worse.

This impression is confirmed by the results of the microsimulation model (Table 2). The impacts on household and personal incomes of the VAT rate increase are significantly higher than those corresponding to the reduction in government spending. Since labour and capital incomes fall together with the rising unemployment, the equivalent income mean suffers a noticeable drop, despite of the rise in public benefits. On the contrary, the scenario 2 reports a situation in terms of income means relatively close to the benchmark.

Although the microsimulation results will be analysed below, the relevance of the linking procedure proposed in this paper should be pointed out. Stopping the analysis in computing average incomes provides the same description obtained with the CGE model in a macroeconomic framework. If the effects of any policy reform were limited to average terms -even when equivalent income is used instead of per capita figures- the actual impact would be underestimated. It would be a new application of the well-known aphorism "a rising tide lifts all boats". However, one can wonder if "actually are all the boats lifting?". The answer is found in the analysis of inequality and poverty. The more unequal a society is, the harder spilling the benefits of economic growth over the whole society is, especially for the poorest people. 
The last four rows in Table 2 broaden the picture described by per capita and equivalent income means.

First, scenario 1 shows some unexpected outcomes. Despite of considerably declining means, inequality in scenario 1 is slightly lower than benchmark, whichever index is used. Its explanation is found in Table 1: while public benefits show some growth, capital and labour incomes fall. These income sources, especially public benefits, and capital, report different patterns depending on the economic trend.

While the formers are mainly earned by the lower tail of the distribution, the latter are much further away from the mean in economic booms and especially related to the high-income part of the distribution. ${ }^{16}$ Therefore, inequality drops in this scenario due to a "general process of worsening": an increase of the VAT would end up in a situation which poorest people would converge because richer people would live worse, instead of improving their income and living conditions.

Even more, this conclusion is reinforced by the poverty indicators. The decrease of incomes along with the rise in unemployment make poverty grows in terms of incidence -more people are expected to live at risk of poverty- and depth -poor people are even poorer. Although the public transfers increase in this scenario and they aim especially at the poorest people, the fall in income means and the evolution of unemployment cause a drop in well-being so dramatic that benefits cannot cope with it.

These implications of the first policy reform would be more significant if the ability of meeting household ends was the variable used to measure the impact. When the VAT rate rises, prices grow so that the households' actual living conditions and consumption will become worse with the consequent fall in household capacity to face future income shocks.

Regarding the scenario 2, their results apparently show that the goal -reducing public deficit- could be reached with only slight decreases in income means. Nevertheless, inequality and poverty stand out because they are clearly higher than benchmark and even higher than the bad results estimated in scenario 1. Again, Table 1 includes the required information to enlighten these figures.

The general reduction of public expenditure would end up in a reduction of labour incomes combined with an increase of capital incomes. This divergence worsens one of the main factors that drive inequality: the shift between capital and labour incomes. The disparity between both income sources in favour of the former has been observed along last decades in most of the OECD countries and it is identified as one of the sources of the rising income inequality in them. Therefore, a reduction of labour incomes combined with an increase of capital incomes make that disparity becoming higher.

Poverty shows the same pattern as inequality. In this case, reducing the public expenditure would make the poverty more spread and deeper. Despite of the rise of public transfers, this growth cannot outweigh the forces supporting poverty and inequality.

\footnotetext{
${ }^{16}$ Figure 3 in the Appendix $\mathrm{C}$ depicts the income decrease in highest quantiles caused by the first simulation.
} 
The last simulation clearly shows the adequacy of the proposal of this paper. By linking the microsimulation model to the CGE model it is possible to measure the distributional impacts and, therefore, go beyond the apparently good results in income means.

Once the simulation results are considered, an additional analysis is put forward to assess to what extent estimated changes in poverty are due to changes in average terms or changes in inequality. Datt and Ravaillon (1992) propose to decompose poverty changes along time in two components, one related to economic growth and the other one to inequality. This decomposition is performed by the following expression:

$$
P_{1}-P_{0}=\left[P\left(\mu^{t_{1}}, \pi^{t_{0}}\right)-P\left(\mu^{t_{0}}, \pi^{t_{0}}\right)\right]+\left[P\left(\mu^{t_{0}}, \pi^{t_{1}}\right)-P\left(\mu^{t_{0}}, \pi^{t_{0}}\right)\right]+R
$$

where $\mu$ and $\pi$ stand for the average income and an inequality measure, respectively; $P\left(\mu^{t_{0}}, \pi^{t_{0}}\right)$ is the FGT index before reforms; $P\left(\mu^{t_{1}}, \pi^{t_{0}}\right)$ the FGT index before reforms when all the pre-reform incomes are multiplied by $\mu^{t_{1}} / \mu^{t_{0}}$; and finally $P\left(\mu^{t_{0}}, \pi^{t_{1}}\right)$ the FGT index after reforms when all the pre-reform incomes are multiplied by $\mu^{t_{0}} / \mu^{t_{1}}$. In this expression, the first term gathers all the components related to growth, the second the ones related to inequality and $R$ is a residual term that collects all the changes not explained by the others.

This residual component can be ruled out by using the Shapley value, so that poverty changes can also be expressed as the addition of only two components related to growth and redistribution:

$$
\begin{aligned}
& P_{1}-P_{0}=C_{1}+C_{2} \\
& C_{1}=\frac{1}{2}\left(\left[P\left(\mu^{t_{1}}, \pi^{t_{0}}\right)-P\left(\mu^{t_{0}}, \pi^{t_{0}}\right)\right]+\left[P\left(\mu^{t_{1}}, \pi^{t_{1}}\right)-P\left(\mu^{t_{0}}, \pi^{t_{1}}\right)\right]\right) \\
& C_{2}=\frac{1}{2}\left(\left[P\left(\mu^{t_{0}}, \pi^{t_{1}}\right)-P\left(\mu^{t_{0}}, \pi^{t_{0}}\right)\right]+\left[P\left(\mu^{t_{1}}, \pi^{t_{1}}\right)-P\left(\mu^{t_{1}}, \pi^{t_{0}}\right)\right]\right)
\end{aligned}
$$

Besides, this methodology requires using absolute measures of poverty or, at least, only one poverty line in both periods with relative measures. Thus, the statistical disturbance in the decomposition coming from different thresholds in time can be avoided. Although any of both poverty lines can be used, the poverty measure anchored at the before-reform period is chosen. ${ }^{17}$

Figures in Table 3 deeply support the conclusions obtained from the previous microsimulation analysis. Decomposing the poverty increase derived from rising the VAT rate shows that almost all this increase is caused by drops in average income (growth component). If the rising taxes had not been changed the income, inequality would have not affected on poverty. Therefore, lower values of inequality coexist with increases in poverty.

17 This methodological option explains why the differences in Table 3 do not coincide with the ones in Table 2 
Table 3 Poverty changes decomposition

\begin{tabular}{|c|c|}
\hline \multicolumn{2}{|l|}{ Scenario 1} \\
\hline Before reform & $0.2154 *$ \\
\hline After reform & $0.2368^{*}$ \\
\hline Difference: (P1-P0) & $0.0214 *$ \\
\hline \multicolumn{2}{|c|}{ Datt-Ravaillon Method: Reference period "before reform” } \\
\hline Growth & $0.0222 *$ \\
\hline Inequality & 0.0009 \\
\hline Residue & -0.0017 \\
\hline \multicolumn{2}{|l|}{ Shapley Method } \\
\hline Growth & $0.0213 *$ \\
\hline Inequality & 0.0001 \\
\hline \multicolumn{2}{|l|}{ Scenario 2} \\
\hline Before reform & $0.2154 *$ \\
\hline After reform & $0.2312 *$ \\
\hline Difference: (P1-P0) & $0.0158 *$ \\
\hline \multicolumn{2}{|c|}{ Datt-Ravaillon Method: Reference period "before reform" } \\
\hline Growth & $0.0060 *$ \\
\hline Inequality & $0.0109 *$ \\
\hline Residue & $-0.0010^{*}$ \\
\hline \multicolumn{2}{|l|}{ Shapley Method } \\
\hline Growth & $0.0055^{*}$ \\
\hline Inequality & $0.0104 *$ \\
\hline
\end{tabular}

Source: DASP v. $2.3 *$ Significance at $5 \%$

Whereas, the outcomes related to Scenario 2 also confirm the microsimulation results. Inequality appears as the main driving factor to poverty increases. Even if income means had not decreased, the poverty difference would have been almost the same. The drop in labour incomes as well as the rise of capital incomes would have driven to uneven impacts on income distribution. Furthermore, despite of the former, poverty would rise because of the evolution of income means, even when no inequality changes.

In sum, the microsimulation model completes the CGE results by allowing one to estimate the distributional impacts. The decision between both policy reforms is between a general worsening of living conditions or keeping the income means at the expense of higher levels of inequality and poverty. Although the models do not provide the best solution, both give enough information to assess the effects of a decision taken by the society.

\section{Conclusions}

The Great Recession has renewed the interest on the relationship between macroeconomic conditions and actual household living conditions. In Europe, as well as other advanced economies, welfare states are on the spotlight. They face an increasing 
demand for social protection as result of the rising unemployment and the falls in household income. However, at the same time, their capacity to provide such protection is constrained due to the austerity measures undertaken to deal with deficit and promote growth in the medium and long-term.

Besides, the increasing trend of inequality in OECD countries from the 70's decade focuses the political and economic debate on this issue. Questions as which is the path of transmitting economic booms or crises to living conditions, or if macroeconomic recovery always means people's wellbeing recovery are key to understand and explain the current and future society.

Given the dramatic drop in GDP, but also in household incomes, the need of exploring this relationship becomes even more important. In addition, this kind of analysis can help one comprehend why so often, political decisions are not understood by public opinion. In this sense, an evaluation of the whole effects of policy changes should be carried out before applying them.

On the other hand, the combination of a CGE model and a microsimulation model represents an appropriate tool for this kind of analysis. Specifically, for our study it offers relevant insights about the impact of austerity measures to achieve Stability and Growth Pact on income inequality. The macroeconomic results point out that the VAT hike has a worse impact on the different sources of households' income compared to the public spending cut. However, in terms of inequality, the increase of VAT rate leads to a less unequal situation compared to the reduction of public expenditure, but also poorer living conditions. That very slight reduction of inequality combined with a noticeable decrease of household income mean depict an impoverished society, as poverty indicators confirm. This result fits well with the existing evidence on the redistributive effects of austerity measures, which mostly points out that spending cuts have more detrimental effects than tax hikes.

These findings also highlight the nexus between income inequality and the distribution of the different income sources in a society. Therefore, the analysis performed in this paper can help the policy designers to choose the best strategies to achieve the socially desirable goals of reducing inequality and poverty, which considered as the defining challenge of our time by the most international institutions.

\section{Appendix A}

CGE model equations.

\section{Production}

Total production. Cobb-Douglas technology:

$$
Q_{j}=\delta_{j} Q D_{j}^{\gamma_{j}} M_{j}^{1-\gamma_{j}}
$$

$Q_{j:}$ Total output of sector $j(j=1,2, \ldots 19)$.

$Q D_{j:}$ Domestic output of sector $j$. 
$M_{j}$ : Equivalent imports for sector $j$.

$\delta_{j}$ : Scale parameter.

$\gamma_{j}$ : Share parameter of domestic output of $j$ in its total production.

Domestic production. Leontief technology:

$$
Q D_{j}=\min \left(\frac{X_{1 j}}{a_{1 j}}, \frac{X_{2 j}}{a_{2 j}}, \ldots, \frac{X_{19 j}}{a_{19 j}}, \frac{V A_{j}}{v_{j}}\right)
$$

$X_{i j}$ : Amount of good $i$ required for the domestic production of $\operatorname{good} j$.

$a_{i j}$ : Minimum amount of good $i$ required to produce one unit of $\operatorname{good} j$.

$V A_{j}:$ Value added of sector $j$.

$v_{j}$ : Minimum amount of value added required to produce one unit of good $j$.

Value added. Cobb-Douglas technology:

$$
V A_{j}=\beta_{j} L_{j}^{\alpha_{j}} K_{j}^{\left(1-\alpha_{j}\right)}
$$

$L_{j:}$ Use of labour in sector $j$.

$K_{j:}$ Use of capital in sector $j$.

$\beta_{j}$ : Scale parameter of sector $j$.

$\alpha_{j}$ : Distribution parameter for the labour factor in sector $j$. The assumption of constant returns to scale implies that the distribution parameter for capital can be calculated as $1-\alpha_{j}$.

Cost of production:

$$
p_{j}=\left(1+\tau_{j}^{p}\right)\left[\sum_{i=1}^{n} q_{j} a_{i j}+\left(1+\tau_{j}^{e s s c}\right) w l_{j}+r k_{j}+\left(1+\tau_{j}^{t}\right) p_{\text {row }} a_{m j}\right]
$$

$p_{j}$ : Unitary cost of production of sector $j$.

$\tau_{j}^{p}$ : Production tax rate of sector $j$.

$q_{j}$ : Consumption price for product $j$-th.

$\tau_{j}^{\text {essc }}$ : Social Security tax rate paid by employers of sector $j$.

$w$ : Price of labour.

$l_{j}$ : Minimum amount of labour required to produce one unit of $\operatorname{good} j$.

$r$ : Price of capital services.

$k_{j}$ : Minimum amount of capital required to produce one unit of good $j$.

$\tau_{j}^{t}$ : Tariff rate of sector $j$.

$p_{\text {row }}$ : Weighted average of the prices of foreign goods.

$a_{m j}:$ Technical coefficients for foreign goods.

Consumption prices:

$$
q_{j}=p_{j}\left(1+\tau_{j}^{v}\right)
$$

$\tau_{j}^{v}:$ Value added tax rate of sector $j$ 


\section{Consumption}

Cobb-Douglas utility function:

$$
U\left(C D_{j}, S D\right)=\left(\prod_{j=1}^{19} C D_{j}^{\varepsilon_{j}}\right) S D^{\left(1-\sum_{j=1}^{19} \varepsilon_{j}\right)}
$$

$U$ : Utility function of the representative consumer.

$C D_{j}$ : Household consumption of $j$-th product.

$S D$ : Household savings.

$\varepsilon_{j}$ : Share parameter of consumption.

Representative household's disposable income:

$$
D I=\left(1-\tau^{d t}\right)\left[w L(1-\mu)+r K+c p i T_{u}+c p i T_{g}+T_{\text {row }}-\tau^{h s s c} w L(1-\mu)\right]
$$

$D I$ : Household's disposable income.

$L$ : Household's endowment of labour.

$K$ : Household's endowment of capital.

cpi: Consumer price index.

$T_{g}$ : Net transfers from the government.

$T_{u}$ : Unemployment benefits.

$T_{\text {row }}$ : Transfers from the rest of the world.

$\tau^{d t}$ : Personal income tax rate.

$\tau^{h s s c}$ : Social Security tax rate paid by employees.

\section{Government}

Taxes on production:

$$
R P=\sum_{j=1}^{19} \tau_{j}^{p}\left[\sum_{i=1}^{19} a_{i j} p_{i} Q D_{j}+\left(\left(1+\tau_{j}^{e s s c}\right) w l_{j}+r k_{j}\right) V A_{j}\right]
$$

$R P$ : Public revenues from taxes on production.

$\tau_{j}^{p}$ : net tax rate on production of sector $j$.

Social Security contribution of employers:

$$
E S S C=\sum_{j=1}^{19} \tau_{j}^{e s s c} w l_{j} V A_{j}
$$

ESSC: Public revenues from Social Security paid by employers. 
Import taxes:

$$
R T=\sum_{j=1}^{19} \tau_{j}^{t} p_{\text {row }} a_{m j} Q_{j}
$$

$R T$ : Public revenues from import taxes.

Value added taxes:

$$
R V=\sum_{j=1}^{19} \tau_{j}^{v}\left(1+\tau_{j}^{p}\right) p_{j} X D_{j}\left(\sum_{j=1}^{19} a_{i j} p_{i} Q D_{j}+\left(\left(1+\tau_{j}^{e s s c}\right) w l_{j}+r k_{j}\right) V A_{j}\right)+\sum_{j=1}^{19} \tau_{j}^{v}\left(1+\tau_{j}^{t}\right) p_{r o w} a_{m j} Q_{j}
$$

$R V$ : Public revenues from value added taxation.

Social Security contribution of employees:

$$
H S S C=\tau^{h s s c} w L(1-\mu)
$$

HSSC: Public revenues from Social Security paid by employees.

$u$ : Endogenous unemployment rate.

Income taxes:

$$
R D=\tau^{d t}\left[w L(1-\mu)+r K+c p i T_{u}+c p i T_{g}+T_{\text {row }}-\tau^{h s s c} w L(1-\mu)\right]
$$

$R D$ : Public revenues from direct taxation.

Public surplus:

$$
\begin{aligned}
& P B=R-c p i T_{u}-c p i T_{g}-\sum_{j=1}^{19} p_{j} D G_{j} \\
& R=R P+E S S C+R T+R V+H S S C+R D
\end{aligned}
$$

$P B$ : Surplus of the government.

$R$ : Total public revenues.

$D G_{j:}$ Government demand of goods and services from sector $j$.

\section{Foreign sector}

$$
F B=\sum_{j=1}^{19} p_{\text {row }} M_{j}-\sum_{j=1}^{19} p_{\text {row }} E_{j}-T_{\text {row }}
$$

$F B$ : Current account balance.

$E \mathrm{j}$ : Exports of sector $j$. 


\section{Investment and savings}

$$
\sum_{j=1}^{19} p_{i n v} I_{j}=p_{i n v} S D+P B+F B
$$

$p_{\text {inv }}:$ Weighted price index of investment goods.

$I_{j}$ : Investment of sector $j$.

\section{Labour market}

$$
\frac{w}{c p i}=\left(\frac{1-u}{1-u_{0}}\right)^{1 / \eta}
$$

$u_{0}$ : Unemployment rate in the benchmark equilibrium.

$\eta$ : Degree of flexibility of the real wage to the unemployment rate.

\section{Appendix B}

See below Table 4

Table 4 Social accounting matrix of Spain for year 2014 (SAMSPA-14)

\begin{tabular}{llll}
\hline$\#$ & Accounts & $\#$ & Institutions accounts \\
\hline 1 & Primary sector & 20 & Labour \\
2 & Extractive industries & 21 & Capital \\
3 & Manufacturing industries & 22 & Households \\
4 & Electric power and gas and water & 23 & Savings / Investment \\
& production and distribution & & \\
5 & Water production and distribution & 24 & Social Security contribution of employers \\
6 & Construction & 25 & Net tax on production \\
7 & Commerce & 26 & Import tax \\
8 & Transport services & 27 & Value added tax \\
9 & Hospitality services & 28 & Income tax \\
10 & Information and communication & 29 & Social Security contributions of employees \\
11 & Financial and insurance services & 30 & Government \\
12 & Real estate services & 31 & Foreign sector \\
13 & Professional services & & \\
14 & Administrative services & & \\
15 & Public administration and defense & & \\
16 & Education services & & \\
17 & Health and social services & & \\
18 & Recreational services & & \\
19 & Other services & & \\
\hline
\end{tabular}

Source: Authors (2017) 


\section{Appendix C}

\section{See below Fig. 3.}

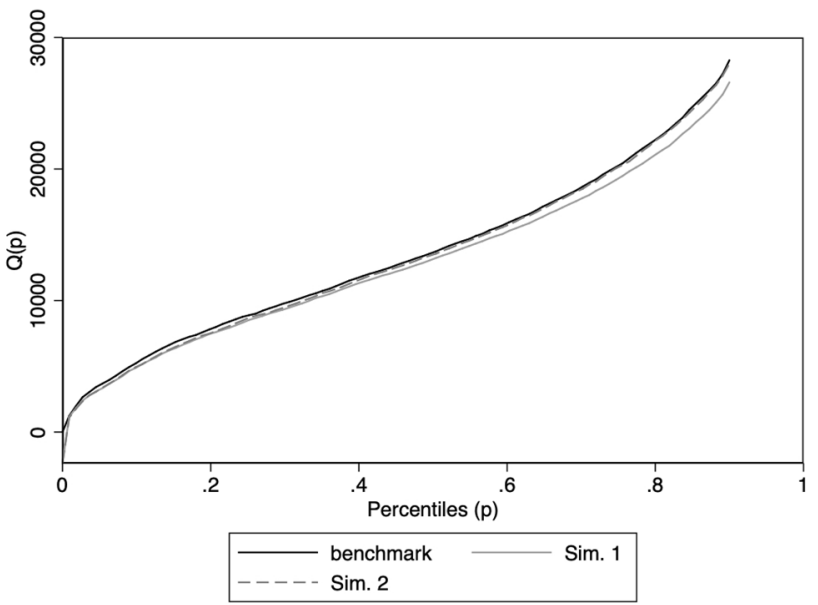

Fig. 3 Percentile curves (0-90). Source: Authors' elaboration

Author contributions CMP, CMA, De MVFJ, PMJ, as all share equal responsibility.

Funding Open Access funding provided thanks to the CRUE-CSIC agreement with Springer Nature. Javier De Miguel-Vélez acknowledges the financial support from Ministerio de Educación, Cultura y Deporte (grant number ECO2016-75204-P) and from Junta de Extremadura European Fund of Regional Development (GR18124). Jesús Pérez-Mayo acknowledges the financial support from Junta de Extremadura and the European Fund of Regional Development (GR18106) Pilar Campoy-Muñoz and M. Alejandro Cardenete acknowledge the financial support from Junta de Andalucía Research Group (Climamodel SEJ-511).

Availability of data and material Not applicable.

Code availability Not applicable.

\section{Declarations}

Conflict of interest The authors declare that they have no conflict of interest.

Open Access This article is licensed under a Creative Commons Attribution 4.0 International License, which permits use, sharing, adaptation, distribution and reproduction in any medium or format, as long as you give appropriate credit to the original author(s) and the source, provide a link to the Creative Commons licence, and indicate if changes were made. The images or other third party material in this article are included in the article's Creative Commons licence, unless indicated otherwise in a credit line to the material. If material is not included in the article's Creative Commons licence and your intended use is not permitted by statutory regulation or exceeds the permitted use, you will need to obtain permission directly from the copyright holder. To view a copy of this licence, visit http://creativecommons.org/licen ses/by/4.0/. 


\section{References}

Agnello, L., \& Sousa, R. (2014). How does fiscal consolidation impact on income inequality? Review of Income and Wealth, 60, 702-726.

Ahmed, S., Ahmed, V., \& Abbas, A. (2010). Taxation Reforms: A CGE-Microsimulation Analysis for Pakistan. MPIA Working Paper 2010-12. https://papers.ssrn.com/sol3/papers.cfm?abstract_id= 1683451. Accessed 15 July 2019

Amuedo-Dorantes, C., \& Borra, C. (2018). Emerging wealth disparities after the storm: Evidence from Spain. Review of Economics of the Household, 16, 1119-1149.

Armington, P. (1969). A theory of demand for products distinguished by place of production. International Monetary Fund Staff Papers, 16, 159-178.

Avram, S., Figari, F., Leventi, C., Levy, H., Nanicke, J., Matsaganis, M., Militaru, E., Paulus, A., Rastringina, O., \& Sutherland, H. (2013). The distributional effects of fiscal consolidation in nine EU countries. EUROMOD Working Paper EM2/13. https://www.econstor.eu/bitstream/10419/ 91653/1/736268049.pdf. Accessed 15 July 2019.

Ayala, L., \& Paniagua, M. (2016). Behavioral Microsimulation of the Impact of In-Work Benefits on Female Labor Supply and Income Distribution: Evidence from Spain. EQUALITAS Working Paper No. 39. http://www.equalitas.es/sites/default/files/WP_39.pdf. Accessed 15 July 2019.

Ayala, L., \& Paniagua, M. (2019). The impact of tax benefits on female labor supply and income distribution in Spain. Review of Economics of the Household, 17, 1025-1048.

Bajo-Rubio, O., \& Gómez-Plana, A. (2015). Alternative strategies to reduce public deficits: taxes vs spending. Journal of Applied Economics, 18(1), 45-70. https://doi.org/10.1016/S1514-0326(15) 30003-9

Ball, L., Furceri, D., Leigh, D., \& Loungani, P. (2013). The distributional effects of fiscal consolidation. IMF Working Paper 13/151. https://www.econstor.eu/handle/10419/91653. Accessed 15 July 2020.

Bank of Spain (2021): "EDP deficit of general government" Retrieved from: https://www.bde.es/ webbde/es/estadis/infoest/a0106e.pdf (Accessed 6 August 2021).

Bargain, O., \& Callan, T. (2010). Analysing the effects of tax-benefit reforms on income distribution: A decomposition approach. The Journal of Economic Inequality, 8(1), 1-21.

Bourguignon, F., \& Spadaro, A. (2006). Microsimulation as a tool for evaluating redistribution policies. The Journal of Economic Inequality, 4(1), 77-106.

Callan, T., Leventi, C., Levy, H., Matsaganis, M., Paulus, A., \& Sutherland, H. (2011). The distributional effects of austerity measures: A comparison of six EU countries. Employment, Social Affairs \& Inclusion. Research note 01/2012- European Commission

Campoy-Muñoz, P., \& Cardenete, M.A., (2017). Una estimación de la Matriz de Contabilidad Social para España 2014. Mimeo.

Cardenete, M. A., \& Sancho, F. (2003). An applied general equilibrium model to assess the impact of national tax changes on a regional economy. Review of Urban \&amp; Regional Development Studies, 15, 55-65.

Cockburn, J, Savard, L \& Tiberti L (2014). Chapter 9. Macro-micro models (pages 251-274) in The handbook of microsimulation modelling, Edited by Cathal O'Donoghue, 2014; Emerald Group Publishing Limited, ISBN: 978-1- 78350-569-2. https://doi.org/10.1108/S0573-85552014293

Coenen, G., Mohr, M., \& Straub, R. (2008). Fiscal consolidation in the euro area: Long-run benefits and short-run costs. Economic Modelling, 25(5), 912-932.

Cowell, F. A. (1995). Measuring inequality. Prentice Hall.

Datt, G., \& Ravaillon, M. (1992). Growth and redistribution components of changes in poverty measures: A decomposition with applications to Brazil and India in the 1980s. Journal of Development Economics, 38, 275-295.

Debortoli, D., \& Galí, J. (2017). Monetary policy with heterogeneous agents: Insights from TANK models. Economics Working Papers 1686, Department of Economics and Business, Universitat Pompeu Fabra, revised May 2021. https://econ-papers.upf.edu/ca/paper.php?id=1686

Feltenstein, A., Mejia, C., Newhouse, D., \& Sedrakyan, G. (2017). The poverty implications of alternative tax reforms: Results from a numerical application to Pakistan. The World Bank. Policy Research Working Paper 8164. https://openknowledge.worldbank.org/handle/10986/27971. Accessed 15 July 2019. 
Foster, J., Greer, J., \& Thorbecke, E. (1984). A class of decomposable poverty measures. Econometrica, 2(81), 761-766.

García-Mainar, I., \& Montuenga-Gómez, V. (2003). The Spanish wage curve: 1994-1996. Regional Studies, 37, 929-945.

Granell, R., \& Fuenmayor, A. (2019). Implementing a negative income tax. Net cost, poverty and inequality effects. Revista Hacienda Pública Española, 228, 83-108.

IMF (2015). Causes and consequences of income inequality: A global perspective. International Monetary Fund Staff Discussion Note 15/13. https://www.imf.org/external/pubs/ft/sdn/2015/sdn1513. pdf. Accessed 20 June 2019.

Kaplan, G., \& Violante, G. L. (2018). Microeconomic heterogeneity and macroeconomic shocks. Journal of Economic Perspectives, 32(3), 167-194.

Kehoe, T. J., Polo, C., \& Sancho, F. (1995). An Evaluation of the performance of an applied general equilibrium model of the Spanish economy. Economic Theory, 6, 115-141.

Levy, H., Mercader-Prats, M., \& Planas, M. (2001). An introduction to ESPASIM: A microsimulation model to assess tax-benefit reforms in Spain. Brazilian Electronic Journal of Economics, 4 (1).

Llambi, C., Laens, S., \& Perera, M. (2016). Assessing the impacts of a major tax reform: A CGEmicrosimulation analysis for Uruguay. International Journal of Microsimulation, 9, 134-166.

Matsaganis, M., \& Laventi, C. (2014). Distributive effects of the crisis and austerity in Seven EU Countries. IMPROVE Working Paper 14/04. http://improve-research.eu/?page_id=30. Accessed 20 June 2019.

McManus, R., Ozkan, F. G., \& Trzeciakiewicz, D. (2021). Fiscal consolidations and distributional effects: Which form of fiscal austerity is least harmful? Oxford Economic Papers, 73(1), 317-349.

National Statistical Institute. (2017). Economically Active Population Survey. Instituto Nacional de Estadística.

National Statistical Institute (2021a): “Annual Spanish National Accounts: main aggregates. Results”. Retrieved from: https://www.ine.es/dyngs/INEbase/en/operacion.htm?c=Estadistica_C\&cid= 1254736177057\&menu=resultados\&idp=1254735576581. (Accessed 6 August 2021).

National Statistical Institute (2021b): “Labour Force Survey: Annual results”. Retrieved from: https:// www.ine.es/dynt3/inebase/en/index.htm?padre=811\&capsel=815. (Accessed 6 August 2021).

Oliver, X., \& Spadaro, A. (2004). A technical description of GLADHISPANIA: A Spanish microsimulation tax-benefit model, DEA WP. https://dea.uib.es/digitalAssets/128/128261_3.pdf. Accessed 2= June 2019.

Oswald, A. J. (1982). The microeconomic theory of the trade union. The Economic Journal, 92, $576-595$.

Paulus, A., Figari, F., \& Sutherland, H. (2017). The design of fiscal consolidation measures in the European Union: Distributional effects and implications for macro-economic recovery. Oxford Economic Papers, 69, 632-654.

Salotti, S., \& Trecroci, C. (2018). Cross-country evidence on the distributional impact of fiscal policy. Applied Economics, 50(51), 5521-5542.

Sanz, J., Romero-Jordán, D., \& Castañer, J. (2009). Análisis de reformas del impuesto sobre la renta personal a partir de microdatos tributarios. El Simulador de la Fundación de las Cajas de Ahorros (FUNCASim). Madrid: FUNCAS.

Sanz, J., Romero-Jordán, D., Castañer, J., Prieto-Rodriguez, J., \& Fernandez, F. (2003). Microsimulacion y comportamiento económico en el análisis de reformas de imposición indirecta. El simulador de impuestos indirectos del Instituto de Estudios Fiscales (SINDIEF). Madrid: Instituto de Estudios Fiscales.

Sanz, J., Romero-Jordán, D., Castañer, J., Prieto-Rodriguez, J., \& Fernández, F. (2004). Microsimulación y comportamiento laboral en las reformas de la imposición sobre la renta personal. El Simulador del Impuesto sobre la Renta Personal del Instituto de Estudios Fiscales (SIRPIEF). Madrid: Instituto de Estudios Fiscales.

Schubert, S. (2018). Minimum income and flat tax revisited: a combined CGE-microsimulation analysis for Germany. Social Science Quarterly, 99(5), 1750-1764.

Spanish Government (2010) Update of the stability programme for Spain 2009 - 2013. Retrieved from: https://www.hacienda.gob.es/CDI/programas $\% 20 \mathrm{de} \% 20$ estabilidad/programa $\% 20 \mathrm{de} \%$ 20estabilidad\%202009-2013.pdf. (Accessed 5 August 2021) 
Spanish Government (2014) Stability programme Spain for Spain 2014-2017. Retrieved from: https:// www.hacienda.gob.es/Documentacion/Publico/GabineteMinistro/Varios/30-04-2014\%20Presenta ci\%C3\%B3nPrograma\%20Estabilidad\%20(ing1\%C3\%A7\%C3\%A9s).pdf Accessed 5 August 2021.

Spanish Government (2021) Stability programmes. Several years. Retrieved from: https://www.hacie nda.gob.es/es-ES/CDI/Paginas/EstrategiaPoliticaFiscal/Programasdeestabilidad.aspx. Accessed 5 August 2021

Woo, J., Bova, E., Kinda, T., \& Zhang, Y. S. (2017). Distributional consequences of fiscal adjustments: what do the data say? IMF Economic Review, 65, 273-307.

Publisher's Note Springer Nature remains neutral with regard to jurisdictional claims in published maps and institutional affiliations.

\section{Authors and Affiliations}

\section{P. Campoy-Muñoz ${ }^{1}$ (D) M. A. Cardenete ${ }^{2,3}$ (D) F. J. De Miguel-Vélez ${ }^{4}$. J. Pérez-Mayo ${ }^{4}$}

M. A. Cardenete

macardenete@uloyola.es

F. J. De Miguel-Vélez

demiguel@unex.es

1 Department of Economics, Universidad Loyola Andalucía, Escritor Castilla Aguayo 4, 14004 Cordoba, Spain

2 Department of Economics, Universidad Loyola Andalucía, Campus Palmas Altas, Energía Solar, 1. Edificio G, 41014 Sevilla, Spain

3 School of Management and Business, Universidad Autonoma de Chile, Región Metropolitana, Chile

4 Department of Economics, Universidad de Extremadura, Elvas Avenue, 06006 Badajoz, Spain 